\title{
Combining ability of physiological traits in forrage maize
}

\section{Capacidade combinatória de caracteristicas fisiológicas em milho forrageiro}

\author{
Greice Daiane Rodrigues Gomes Redivo ${ }^{1}$, Marcos Ventura Faria' ${ }^{1}$, Jocimar Costa Rosa ${ }^{3 *}$, \\ Elizabeth Orika Ono ${ }^{2} \mathbb{D}$, João Domingos Rodrigues ${ }^{2} \mathbb{D}$, Elisa Adriano ${ }^{1} \mathbb{D}$
}

\author{
'Universidade Estadual do Centro-Oeste. Programa de Pós-Graduação em Agronomia, Guarapuava, PR, Brasil \\ ${ }^{2}$ Universidade Estadual Paulista Júlio de Mesquita Filho/Unesp, Botucatu, SP, Brasil \\ ${ }^{3}$ Universidade Estadual de Maringá/UEM, Programa de Pós-Graduação em Genética e Melhoramento, Maringá, PR, Brasil \\ ${ }^{*}$ Corresponding author: joce_jcosta@hotmail.com \\ Received in August 26, 2020 and approved in October 21, 2020
}

\begin{abstract}
The exploitation of the existing genetic variability for the physiological traits related to the yield and quality of maize forage can assist in the development of superior inbred lines and hybrids. The objective of this work was to evaluate the general and the specific combining ability and the nature of gene effects of physiological and chemical traits of forage maize genotypes. Two groups of genotypes and 16 hybrids resulting from a 4x4 partial diallel scheme were evaluated. Group I consisted of two commercial hybrids (AG8025, P30B39) and two elite inbred lines (LEM2 and LEM3). Group II consisted of four experimental inbred lines originated from different populations of forage maize breeding program. In total, 24 treatments were evaluated, formed by the genotypes of both groups and the respective crossings. The traits evaluated were: $\mathrm{CO}_{2}$ assimilation $(A)$, stomatal conductance $(g s)$, internal $\mathrm{CO}_{2}$ concentration $(C i)$, transpiration $(E)$, calculated activity of Rubisco ( $A / C i$ ) and efficiency of water use (A/E). Forage acid detergent fiber (ADF), neutral detergent fiber (NDF) and digestibility in situ were obtained. There was a predominance of non-additive gene effects for most of the chemical and physiological traits. Crossings LEM2 × 203-218.3, LEM3 x 201-107.2, LEM2 x 101-7.2 and LEM3 x 101-7.2 stood out regarding CO $_{2}$ assimilation, and are indicated for future research considering the physiological traits. Inbred lines 101-7.2 and 203-218.3 presented high concentration of favorable alleles to increase carboxylation efficiency, in which inbred line 101-7.2 stood out for NDF, ADF and DIG. Inbred line 201107.2 has a high concentration of favorable alleles for efficiency of water use. Physiological parameters can assist the selection of inbred lines and hybrids in maize breeding for forage purpose.
\end{abstract}

Index terms: $\mathrm{CO}_{2}$ assimilation; stomatal conductance; internal $\mathrm{CO}_{2}$ concentration; water efficiency; gaseous exchanges.

\section{RESUMO}

A exploração da variabilidade genética existente para características fisiológicas relacionadas com a produtividade e a qualidade da forragem de milho pode auxiliar no desenvolvimento de linhagens e híbridos superiores. O objetivo deste trabalho foi avaliar a capacidade geral e específica de combinação e a natureza dos efeitos genicos de características fisiológicas e químicas de genótipos de milho forrageiro. Foram avaliados dois grupos de genótipos e 16 híbridos resultantes dos cruzamentos em esquema de dialelo parcial 4x4. O grupo I foi constituído por dois híbridos comerciais (AG8025, P30B39) e duas linhagens elite (LEM2 e LEM3). O grupo II foi constituído por quatro linhagens experimentais oriundas de diferentes populações do programa de melhoramento do milho forrageiro da UNICENTRO. No total foram avaliados 24 tratamentos, constituídos pelos genótipos de ambos os grupos e os respectivos cruzamentos. As características avaliadas foram assimilação de $\mathrm{CO}_{2}(A)$, condutância estomática (gs), concentração interna de $\mathrm{CO}_{2}(C i)$, transpiração $(E)$, atividade calculada da Rubisco $(A / C i)$ e eficiência de uso da água (A/E). Foram obtidos os teores de fibra em detergente ácido (FDA), fibra em detergente neutro (FDN) e a digestibilidade in situ da forragem. Houve predomínio de efeitos gênicos não aditivos para a maioria das características químicas e fisiológicas. Os cruzamentos LEM2 x 203-218,3, LEM3 x 201-107,2, LEM2 × 101-7,2 e LEM3 × 101-7,2 se destacaram quanto à assimilação de CO2, sendo indicados para pesquisas futuras considerando as características fisiológicas. As linhagens 101-7.2 e 203-218.3 apresentaram alta concentração de alelos favoráveis para aumentar a eficiência da carboxilação, em que a linhagem 101-7.2 se destacou para NDF, ADF e DIG. A linhagem endogâmica 201-107.2 possui alta concentração de alelos favoráveis para eficiência do uso da água. Parâmetros fisiológicos podem auxiliar na seleção de linhagens e híbridos no melhoramento do milho forrageiro.

Termos de indexação: Assimilação de $\mathrm{CO}_{2}$; condutância estomática; concentração interna de $\mathrm{CO}_{2}$; eficiência hídrica; trocas gasosas. 


\section{INTRODUCTION}

Physiological and chemical variables are important to understand the differences in the performance of vegetal species and selection of superior genotypes. These traits are used to verify the culture adaptation to new environments, interspecific competition and effects of handling systems, in addition to the yield potential of different genotypes (Alvarez; Crusciol; Nascente, 2012; Chen et al., 2018).

The interaction of environmental factors such as light, temperature, $\mathrm{CO}_{2}$ concentration and availability and use of water and nutrients affect several traits substantially, being determining factors in the selection of genotypes with greater photosynthetic efficiency, better water use and, as a result, higher productivity, since more efficient genotypes in physiological and chemical traits tend to present higher yield potential (Alvarez; Crusciol; Nascente, 2012; Lins et al., 2017).

Vegetables absorb carbon dioxide from the atmospheric air together with light and water electrons, performing the photosynthesis, which, in short, is the reduction of this atmospheric $\mathrm{CO}_{2}$ in organic carbon, giving origin to organic molecules for growth and development (Taiz; Zeiger, 2013).

Plants intercept the necessary light for the photosynthesis by the leaves, and the gaseous exchange takes place through the stomatal pores on the foliar surface. The process of opening and closing of the stomata mainly related to light intensity and the hydration state of the leaf. Propitious conditions to carbon fixation favor the opening of the stoma, while the propitious conditions to water loss promote its closing (Taiz; Zeiger, 2013).This mechanism limits the flow of $\mathrm{CO}_{2}$ to the internal side of the leaf and may limit the $\mathrm{CO}_{2}$ diffusion rate to the internal part of the leaf, with direct effects on photosynthesis and growth, while it restricts the water flow of the leaf to the atmosphere, decreasing transpiration and directly influencing plant productivity (Huang et al., 2017; Sun et al., 2014).

Maize is a $\mathrm{C} 4$ plant, characterized by a mechanism of $\mathrm{CO}_{2}$ concentration that involves a coordinated functioning between the mesophile and the bundle sheath cells (Retta et al., 2016). It presents a low point of $\mathrm{CO}_{2}$ compensation, a high photosynthetic rate and low water consumption for the formation of fresh matter (Hlatywayo et al., 2016; Huang et al., 2017). This functioning confers a higher photosynthetic net rate if compared to a $\mathrm{C} 3$ plant, since it presents low water loss, it can be cultivated in hot environments with high luminous intensity, and it adapts well to the tropical climate due to its low or null photorespiration (Wu et al., 2016).
Studies on gene effects and combining ability on physiological traits in forage maize are not very common. Ali et al. (2015) carried out a genetic analysis of forage maize genotypes for several physiological traits and concluded that the selection of genotypes with a higher photosynthetic rate, better efficiency of gaseous exchanges and water use can be determining in the increase of forage yield and productivity, which justifies more studies on this area.

The evaluation of physiological and chemical parameters can also be used in an attempt to explain differences of a genetic order (Peixoto et al., 2011). The current search for more efficiency in water use can be applied in the production of forage of good quality, since physiological factors influence and condition plant development and forage maturation (Guarda; Campos, 2014).

The aim of this work was to evaluate the general and specific combining ability and the nature of gene effects of physiological and chemical traits of forage maize genotypes.

\section{MATERIAL AND METHODS}

Two groups of genotypes and 16 hybrids were evaluated, resulting from the crossings between the groups, in a $4 \times 4$ partial diallel scheme. Group I consisted of two commercial hybrids (AG8025, P30B39), and two inbred lines (LEM2 and LEM3), used as testers of the inbred lines of group II. Group II consisted offour experimental inbred lines originated from different populations of the breeding program of forage maize of the UNICENTRO. In total, 24 treatments were evaluated, formed by genotypes of both groups and the respective crossings.

The parcels were formed by 2 lines of 5 meters, with spacing of $0.80 \mathrm{~m}$, resulting in a final density equivalent to 69.200 plants ha' ${ }^{-1}$.

In the first and second crop season, $250 \mathrm{~kg} \mathrm{ha}^{-1}$ of the NPK 04-20-20 formulation was used in basis fertilization. The nitrogen fertilizations in top dressing were carried out when the plants reached between 3 leaves (V3 stage) and 5 leaves (V5 stage), with an application of $280 \mathrm{~kg} \mathrm{ha}^{-1} \mathrm{of}$ urea $(46 \%$ of $\mathrm{N})$ in each stage, totaling $257,6 \mathrm{~kg} \mathrm{ha}^{-1}$ of $\mathrm{N}$.

Three evaluations were carried out in the first crop season, at 42, 63 and 84 days after emergence (DAE), and two evaluations in the second crop season, at 21 and $63 \mathrm{DAE}$, due to the fact that the crop cycle is shorter. The 21 DAE corresponded to phenological stages $\mathrm{V} 3-\mathrm{V} 4$, when the definition of productive potential takes place; $42 \mathrm{DAE}$ corresponded to V11-V12, when the number of grains and spike size are defined; 63 DAE corresponded to the VT stage, when flowering and pollination took place and; $84 \mathrm{DAE}$ corresponded to the beginning of grain filling (Cañas et al., 2017). 
Measurements of gaseous exchanges were carried out with the Infra Red Gas Analyser - IRGA, equipment, LI-6400, LI-COR model. The measurements were carried out between 9 and 11 o'clock on sunny days, in leaves fully expanded from the plants of each parcel. The $\mathrm{CO}_{2}$ concentration and the light used during the evaluations were the ones existing in the environment. The values of $\mathrm{CO}_{2}$ assimilation rate (A) $\left(\mu \mathrm{mol} \mathrm{CO} \mathrm{CO}^{-2} \mathrm{~s}^{-1}\right)$ and of the transpiration rate $(E)\left(\mathrm{mmol}\right.$ water vapor $\left.\mathrm{m}^{-2} \mathrm{~s}^{-1}\right)$ were obtained. The internal $\mathrm{CO}_{2}$ concentration $(\mathrm{Ci})(\mu \mathrm{mol} \mathrm{CO}$ $\mathrm{mol}^{-1}$ air $)$ and the stomatal conductance $\left(g_{s}\right)\left(\mathrm{mol} \mathrm{m}^{-2} \mathrm{~s}^{-1}\right)$ were calculated by the general equation of gaseous exchanges of Von Caemmerer and Farquhar (1981).

The efficiency of water use $(A / E)\left(\mu \mathrm{molCO}_{2} /\right.$ mmol $\mathrm{H}_{2} \mathrm{O}^{-1}$ ) was determined through the ratio between the $\mathrm{CO}_{2}$ assimilation rate and the transpiration rate, and the carboxylation efficiency or the calculated activity of Rubisco $(A / C i)\left(\mu \mathrm{mol} \mathrm{m} \mathrm{m}^{-2} \mathrm{~s}^{-1} \mathrm{~Pa}^{-1}\right)$ was determined through the ratio between the $\mathrm{CO}_{2}$ assimilation rate and the internal $\mathrm{CO}_{2}$ concentration in the leaf, according to Pimentel (2011).

The forage was obtained with the plants in the reproductive stages from pasty to chalky grain, at the point of $3 / 4$ of the milkline, which corresponds to the silage point. Acid detergent fiber (ADF-\%) and neutral detergent fiber (NDF-\%) were evaluated according to Van Soest, Robertson and Lewis (1991). The digestibility in situ of the forage dry mass (DIG- $\%$ ) was evaluated in accordance with Pereira et al. (2004).

After verifying the normality of errors and homogeneity of the variances by the Bartlett test, the individual and joint analyses of variance were carried out. The individual and joint partial diallel analyses were performed according to method 2 and model 1 proposed by Griffing (1956) and adapted for partial diallels by Geraldi and Miranda Filho (1988), aiming at estimating the general combining ability (GCA) of the genitors and the specific combining ability (SCA) from the $p q$ hybrid combinations, where $p$ inbred lines of group I were crossed with $q$ tester genotypes of group II. The statistical software GENES was used (Cruz, 2013).

\section{RESULTS AND DISCUSSION}

The mean squares regarding the general combining ability (GCA) and specific combining ability (SCA) (Tables 1 and 2), when significant, indicate that the genitors of both groups differed from each other in the frequency of favorable alleles, and indicate that the traits evaluated can be used as parameters of selection aiming at the obtainment of hybrids with better physiological efficiency (Ali et al., 2014a; Peixoto et al., 2011; Tiwari et al., 2014).

In the several evaluations, for most of the traits there was the predominance of non-additive effects, since the quadratic components of the SCA were higher than those of the GCA (Tables 1 and 2), agreeing with the results by Ali et al. (2014b), which favors the high complementarity of parentals considering physiological efficiency. The SCA is expressed because of the effects of dominance, overdominance and epistasis and of the differences in the allelic frequencies of the genitors for the loci involved in the control of a certain trait (Hallauer; Carena; Miranda Filho, 2010; Wang et al., 2018). The predominance of genes of non-additive effects was also verified for forage traits, such as acid detergent fiber (ADF), neutral detergent fiber (NDF) and digestibility by Rosa et al. (2020), so that the selection based on genes of non-additive effects is efficient for both physiological traits and traits related to forage quality.

For the the $\mathrm{CO}_{2}$ assimilation rate $(A)$ there were significant effects of the genotypes and SCA, at 42 days after emergence in the first crop season (42 DAE-1). There were significant effects for all sources of variation in the evaluation carried out at 63 DAE-1 (Table 1). At 63 days after emergence, in the second crop season (63 DAE-2), there were significant effects for GCA-I and GCA-II (Table 2).

For stomatal conductance $(g s)$, in the evaluation carried out at 42 DAE-1, there was no significant effect only for GCA of group II (Table 1). For internal $\mathrm{CO}_{2}$ concentration $(\mathrm{Ci})$, at $42 \mathrm{DAE}-1$, there was a significant effect of groups and of the GCA - I. In the evaluation carried out at 63 DAE-1 there was no significant effect only for the SCA and, in contrast, at 84 DAE-1 only SCA was significant (Table 1). At 21 DAE-2 there was a significant effect for the groups, GCA-I and SCA. At 63 DAE-2 there was a significant effect only for GCA-I (Table 2).

For transpiration $(E)$, at 42 DAE-1, there was a significant effect of genotypes GCA-I and SCA. At 63 DAE-1 there was a significant effect of genotypes GCAII and SCA. At 84 DAE-1 there was significance only for GCA-II (Table 1). In the evaluation, at 21 DAE-2, the effect was significant for genotypes GCA-I, GCA-II and SCA, and at 63 DAE-2 of the GCA- I (Table 2). For the $(\mathrm{A} / \mathrm{C} \mathrm{i})$ ratio there was a significant effect of GCA-II at 63 DAE-1 and of GCA-I at 84 DAE-1, (Table 1). At 21 DAE2 , there was a significant effect for genotypes, groups, GCA-I and GCA-II, and at 63 DAE-2, it was significant for groups and SCA (Table 2). 
Table 1: Summary of the partial diallel analysis related to traits $\mathrm{CO}_{2}$ assimilation $(A)\left(\mu \mathrm{mol} \mathrm{CO}_{2} \mathrm{~m}^{-2} \mathrm{~s}^{-1}\right)$, stomatal condunctance $(g s)\left(\mathrm{mol} \mathrm{m}^{-2} \mathrm{~s}^{-1}\right)$, internal $\mathrm{CO}_{2}$ concentration $(\mathrm{Ci})\left(\mu \mathrm{mol} \mathrm{CO}_{2} \mathrm{~mol}^{-1}\right.$ air), transpiration $(E)$ (mmol water vapor $\left.\mathrm{m}^{-2} \mathrm{~s}^{-1}\right)$, calculated activity of Rubisco $(A / C i)\left(\mu \mathrm{mol} \mathrm{m}^{-2} \mathrm{~s}^{-1} \mathrm{~Pa}^{-1}\right)$ and efficiency of water use $(A / E)\left(\mu \mathrm{mol} \mathrm{CO}_{2} /\right.$ mmol $\mathrm{H}_{2} \mathrm{O}^{-1}$ ), evaluated at 42,63 and 84 days after emergence in the first crop season (DAE-1).

\begin{tabular}{|c|c|c|c|c|c|c|c|}
\hline $\begin{array}{l}\text { Source of } \\
\text { variation }\end{array}$ & DF & $\begin{array}{c}\mathrm{CO}_{2} \text { Assimilation } \\
\text { rate }(A)\end{array}$ & $\begin{array}{c}\text { Stomatal } \\
\text { condunctance (gs) }\end{array}$ & $\begin{array}{c}\text { Internal } \mathrm{CO}_{2} \\
\text { concentration }(\mathrm{Ci})\end{array}$ & $\begin{array}{l}\text { Transpiration } \\
(E)\end{array}$ & $\mathrm{A} / \mathrm{Ci}$ & $A / E$ \\
\hline \multicolumn{8}{|c|}{$1^{\text {st }}$ Crop Season -Evaluation at 42 DAE-1 } \\
\hline SV & DF & & & MS & & & \\
\hline Genotypes & 23 & $26.64^{*}$ & $0.07^{\star}$ & 55.52 & $1.21 *$ & 0.01 & $0.06^{*}$ \\
\hline Groups & 1 & $49.56^{*}$ & $0.29 *$ & $169.65^{*}$ & 0.10 & 0.00 & $0.09 *$ \\
\hline GCA - I & 3 & 8.73 & $0.10 *$ & $229.65 *$ & $2.43^{*}$ & 0.01 & 0.00 \\
\hline GCA - ॥ & 3 & 10.19 & 0.01 & 26.69 & 0.49 & 0.00 & $0.06^{*}$ \\
\hline SCA & 16 & $31.65^{*}$ & $0.06 *$ & 21.14 & $1.19 *$ & 0.02 & $0.06 *$ \\
\hline Residue & 23 & 16.68 & 0.03 & 65.15 & 1.10 & 0.00 & 0.04 \\
\hline \multicolumn{8}{|c|}{ Quadratic Components (\%) } \\
\hline GCA \% & & 52.86 & 23.02 & 69.45 & 31.59 & 41.62 & 17.08 \\
\hline SCA $\%$ & & 47.14 & 76.98 & 30.55 & 68.41 & 58.38 & 82.92 \\
\hline \multicolumn{8}{|c|}{$1^{\text {st }}$ Crop Season -Evaluation at 63 DAE-1 } \\
\hline SV & DF & & & MS & & & \\
\hline Genotypes & 23 & $102.88^{*}$ & 0.06 & $1.586 .90 \star$ & $2.42 *$ & 0.24 & 1.81 \\
\hline Groups & 1 & $299.29 *$ & 0.02 & $2.936 .82 *$ & 1.12 & 0.19 & 0.00 \\
\hline GCA - I & 3 & $80.43^{*}$ & 0.00 & $2.755 .63^{\star}$ & 0.36 & 0.16 & 1.37 \\
\hline GCA - II & 3 & $180.12^{*}$ & 0.01 & $1.579 .51 *$ & $5.67^{*}$ & $0.63 *$ & 1.37 \\
\hline SCA & 16 & $80.34 *$ & 0.01 & 1.284 .78 & $2.36^{*}$ & 0.18 & $2.09 *$ \\
\hline Residue & 23 & 58.55 & 0.01 & 1.496 .94 & 1.69 & 0.28 & 1.83 \\
\hline \multicolumn{8}{|c|}{ Quadratic Components (\%) } \\
\hline GCA \% & & 37.81 & 41.34 & 86.35 & 32.37 & 44.83 & 19.70 \\
\hline SCA $\%$ & & 62.19 & 58.66 & 13.65 & 67.63 & 55.17 & 80.30 \\
\hline \multicolumn{8}{|c|}{$1^{\text {st }}$ Crop Season - Evaluation at 84 DAE-1 } \\
\hline SV & DF & & & MS & & & \\
\hline Genotypes & 23 & 72.37 & 0.01 & 733.25 & 2.66 & 0.45 & $0.98^{*}$ \\
\hline Groups & 1 & 55.76 & 0.01 & 53.32 & 0.01 & 0.01 & $1.15^{*}$ \\
\hline GCA - I & 3 & 27.06 & 0.03 & 145.88 & 2.52 & $0.63 *$ & 0.26 \\
\hline GCA - ॥ & 3 & 97.58 & 0.02 & 266.03 & $4.29 *$ & 0.45 & $1.79 *$ \\
\hline SCA & 16 & 77.18 & 0.01 & $973.48 *$ & 2.54 & 0.44 & $0.96^{*}$ \\
\hline Residue & 23 & 98.80 & 0.01 & 880.31 & 4.14 & 0.46 & 0.64 \\
\hline \multicolumn{8}{|c|}{ Quadratic Components (\%) } \\
\hline GCA \% & & 23.24 & 29.87 & 7.35 & 33.41 & 31.65 & 28.55 \\
\hline SCA $\%$ & & 76.76 & 70.13 & 92.65 & 66.59 & 68.35 & 71.45 \\
\hline
\end{tabular}

* Significant by $\mathrm{F}$ test at 5\% probability. 
Table 2: Summary of the individual partial diallel analysis related to traits $\mathrm{CO}_{2}$ assimilation $(A)\left(\mu \mathrm{mol} \mathrm{CO}_{2} \mathrm{~m}^{-2} \mathrm{~s}^{-1}\right)$, stomatal conductance $(g s)\left(\mathrm{mol} \mathrm{m}^{-2} \mathrm{~s}^{-1}\right)$, internal $\mathrm{CO}_{2}$ concentration $(C i)\left(\mu \mathrm{mol} \mathrm{CO}_{2} \mathrm{~mol}^{-1}\right.$ air), transpiration $(E)(\mathrm{mmol}$ water vapor $\left.\mathrm{m}^{-2} \mathrm{~s}^{-1}\right)$, calculated activity of Rubisco $(A / C i)\left(\mu \mathrm{mol} \mathrm{m}^{-2} \mathrm{~s}^{-1} \mathrm{~Pa}^{-1}\right)$ and efficiency of water use $(A / E)(\mu \mathrm{mol}$ $\left.\mathrm{CO}_{2} / \mathrm{mmol} \mathrm{H}_{2} \mathrm{O}^{-1}\right)$, evaluated at 21 and 63 days after emergence in the second crop season (DAE-2).

\begin{tabular}{|c|c|c|c|c|c|c|c|}
\hline $\begin{array}{l}\text { Source of } \\
\text { variation }\end{array}$ & DF & $\begin{array}{c}\mathrm{CO}_{2} \text { Assimilation } \\
(A)\end{array}$ & $\begin{array}{c}\text { Stomatal } \\
\text { condunctance } \\
\text { (gs) }\end{array}$ & $\begin{array}{c}\text { Internal } \mathrm{CO}_{2} \\
\text { concentration }(\mathrm{Ci})\end{array}$ & $\begin{array}{c}\text { Transpiration } \\
(E)\end{array}$ & $\mathrm{A} / \mathrm{Ci}$ & $A / E$ \\
\hline \multicolumn{8}{|c|}{$2^{\text {nd }}$ Crop Season -Evaluation at 21 DAE-2 } \\
\hline SV & DF & & & MS & & & \\
\hline Genotypes & 23 & 38.91 & 0.02 & $309.71 *$ & $1.36 *$ & $12.92^{*}$ & 0.40 \\
\hline Groups & 1 & 23.20 & 0.01 & $872.22^{*}$ & 0.56 & $46.22 *$ & 0.00 \\
\hline GCA - I & 3 & 45.38 & 0.03 & $800.65^{*}$ & $1.48^{*}$ & $19.08^{*}$ & 0.46 \\
\hline GCA - II & 3 & 41.33 & 0.02 & 91.19 & 1.11 * & $16.59 *$ & 0.21 \\
\hline SCA & 16 & 38.22 & 0.01 & $223.47 *$ & $1.43 *$ & 8.99 & 0.44 \\
\hline Residue & 46 & 50.70 & 0.01 & 173.02 & 1.10 & 12.63 & 0.47 \\
\hline \multicolumn{8}{|c|}{ Quadratic Components (\%) } \\
\hline GCA \% & & 29.84 & 28.13 & 42.80 & 25.40 & 42.65 & 22.14 \\
\hline SCA $\%$ & & 70.16 & 71.87 & 57.20 & 74.60 & 57.35 & 77.86 \\
\hline \multicolumn{8}{|c|}{$2^{\text {nd }}$ Crop Season -Evaluation at 63 DAE-2 } \\
\hline SV & DF & & & MS & & & \\
\hline Genotypes & 23 & 81.60 & 0.03 & 518.09 & 2.25 & 79.05 & 0.50 \\
\hline Groups & 1 & 2.37 & 0.01 & 502.08 & 0.87 & $196.74 *$ & 0.13 \\
\hline GCA - I & 3 & $205.32 *$ & 0.01 & $1.047 .03 *$ & $7.52^{*}$ & 48.79 & $0.69 *$ \\
\hline GCA - II & 3 & $194.78 *$ & 0.02 & 130.33 & 1.40 & 42.93 & $1.13^{*}$ \\
\hline SCA & 16 & 42.14 & 0.00 & 492.62 & 1.51 & $84.14^{*}$ & 0.37 \\
\hline Residue & 46 & 105.56 & 0.01 & 732.4 & 7.59 & 83.37 & 0.54 \\
\hline \multicolumn{8}{|c|}{ Quadratic Components (\%) } \\
\hline GCA \% & & 64.03 & 7.55 & 30.95 & 52.46 & 16.97 & 47.58 \\
\hline SCA \% & & 35.97 & 92.45 & 69.05 & 47.54 & 83.03 & 52.42 \\
\hline
\end{tabular}

* Significant by $\mathrm{F}$ test at $5 \%$ probability.

For the ratio between $\mathrm{CO}_{2}$ assimilation and transpiration $(A / \mathrm{E})$, at $42 \mathrm{DAE}-1$, there was a significant effect of genotypes, groups, of GCAII and SCA, as well as of the SCA at 63 DAE-1. At 84 DAE-1 there was no significant effect only for GCAI (Table 1). There was a significant effect for GCA of both groups at 63 DAE-2 (Table 2).

The estimates of the effects of the SCA of $\mathrm{CO}_{2}$ assimilation $(A)$, at 42 DAE-1, demonstrated a good performance of crossing LEM2 x 203-218.3 $\left(\hat{\mathrm{s}}_{\mathrm{ij}}=3.93\right.$ $\mu \mathrm{mol} \mathrm{CO} \mathrm{m}^{-2} \mathrm{~s}^{-1}$ ) (Table 3), which presented the highest $\mathrm{CO}_{2}$ assimilation rate $(A)$ at $42 \mathrm{DAE}-1\left(68.25 \mu \mathrm{mol} \mathrm{CO}_{2} \mathrm{~m}^{-2} \mathrm{~s}^{-1}\right)$ among all the evaluated genotypes (Supplement 1). The crossing LEM2 x 201-107.2 also had favorable estimates of SCA $(A)$ at 42 DAE-1 (Table 3).
Hybrid combinations with favorable estimates of SCA, whose genitors have presented favorable estimates of the GCA, are desirable, as well (Oliboni et al., 2013). In this sense, crossing LEM2 x 101-7.2 $\left(\hat{\mathrm{s}}_{\mathrm{ij}}=4.92 \mu \mathrm{mol} \mathrm{CO} \mathrm{m}_{2} \mathrm{~m}^{-2} \mathrm{~s}^{-1}\right.$, Table 3$)$ stood out at 63 DAE-1, with $(A)$ mean value of $39.06 \mu \mathrm{mol} \mathrm{CO}_{2} \mathrm{~m}^{-2} \mathrm{~s}^{-1}$ (Supplement 1), considering that both genitors had positive estimates of GCA $(A)$ (Table 3 ). The increase of $\mathrm{CO}_{2}$ assimilation is directly related to photosynthetic efficiency and, consequently, to dry mass yield and grain yield, directly reflecting on forage production (Pimentel, 2011), as it can be observed in Figure 1, where the most efficient genotypes in $\mathrm{CO}_{2}$ assimilation presented better forage quality. 
Table 3: Estimates of general combining ability $\left(\hat{g}_{i}\right.$ and $\left.\hat{g}_{\mathrm{j}}\right)$ and specific combining ability $\left(\hat{\mathrm{s}}_{\mathrm{ij}}\right)$ of $\mathrm{CO}_{2}$ assimilation (A) $\left(\mu \mathrm{mol} \mathrm{CO}_{2} \mathrm{~m}^{-2} \mathrm{~s}^{-1}\right)$, of 24 maize genotypes evaluated in a $4 \times 4$ partial diallel at 42 and 63 days after emergence in the first crop season (DAE-1) and at 63 days after emergence in the second crop season (DAE2), in Guarapuava-PR.

\begin{tabular}{|c|c|c|c|c|c|c|}
\hline \multirow{8}{*}{$\begin{array}{c}\text { Evaluation } \\
42 \text { DAE-1 } \\
1^{\text {st }} \text { Crop Season }\end{array}$} & & & \multicolumn{4}{|c|}{ Group II } \\
\hline & \multicolumn{2}{|l|}{ Group I } & $101-7.2$ & 201-107.2 & $202-160.1$ & 203-218.3 \\
\hline & & GCA & 0.26 & 0.24 & -1.16 & 0.65 \\
\hline & LEM3 & -0.15 & -0.45 & 3.84 & 2.16 & 2.32 \\
\hline & LEM2 & 0.64 & -0.80 & 3.80 & 1.89 & 3.93 \\
\hline & AG8025 & -0.97 & 1.76 & 2.24 & 2.04 & 2.42 \\
\hline & P30B39 & 0.49 & 2.63 & 0.26 & 5.20 & -1.00 \\
\hline & \multicolumn{2}{|l|}{$\mathrm{SD}\left(\mathrm{s}_{\mathrm{j} j \mathrm{j}}\right): 1.05$} & \multicolumn{4}{|c|}{$\mathrm{SD}\left(\mathrm{s}_{\mathrm{ij}}\right): 2.53$} \\
\hline \multirow{7}{*}{$\begin{array}{c}\text { Evaluation } \\
\text { 63 DAE-1 } \\
1^{\text {st }} \text { Crop Season }\end{array}$} & & & \multicolumn{4}{|c|}{ Group II } \\
\hline & \multicolumn{2}{|l|}{ Group I } & $101-7.2$ & 201-107.2 & $202-160.1$ & 203-218.3 \\
\hline & & GCA & 2.64 & -3.02 & 3.15 & -2.77 \\
\hline & LEM3 & 1.45 & 1.94 & 8.58 & 1.07 & -12.45 \\
\hline & LEM2 & 2.33 & 4.92 & -8.13 & 1.29 & 6.09 \\
\hline & AG8025 & -1.50 & 3.73 & -0.51 & 1.91 & -0.11 \\
\hline & Р30B39 & -2.28 & 4.00 & -9.43 & -5.84 & 0.97 \\
\hline & \multicolumn{2}{|l|}{$\mathrm{SD}\left(\mathrm{s}_{\mathrm{ij}}\right): 3.66$} & \multicolumn{4}{|c|}{$\mathrm{SD}\left(\mathrm{s}_{\mathrm{ij}}\right): 4.75$} \\
\hline \multirow{8}{*}{$\begin{array}{c}\text { Evaluation } \\
63 \text { DAE-2 } \\
2^{\text {nd }} \text { Crop Season }\end{array}$} & & & \multicolumn{4}{|c|}{ Group II } \\
\hline & \multicolumn{2}{|l|}{ Group I } & $101-7.2$ & 201-107.2 & $202-160.1$ & $203-218.3$ \\
\hline & & GCA & -3.41 & 4.87 & -0.87 & -0.57 \\
\hline & LEM3 & 4.24 & 0.65 & 0.24 & -3.05 & -2.32 \\
\hline & LEM2 & 1.03 & -3.99 & -8.95 & 1.82 & 0.92 \\
\hline & AG8025 & -0.97 & -6.03 & 5.03 & 1.60 & 5.88 \\
\hline & Р30B39 & -4.30 & 2.39 & 2.08 & -1.90 & -6.90 \\
\hline & \multicolumn{2}{|l|}{$\mathrm{SD}\left(\mathrm{s}_{\mathrm{j} j \mathrm{j}}\right): 4.91$} & \multicolumn{4}{|c|}{$\mathrm{SD}\left(\mathrm{s}_{\mathrm{ij}}\right): 3.37$} \\
\hline
\end{tabular}

At 63 DAE-2, the inbred line LEM3 had the highest $\operatorname{GCA}(A)$ estimate among the testers of group I $\left(\hat{g}_{\mathrm{i}}=4.24\right.$ $\left.\mu \mathrm{mol} \mathrm{CO}_{2} \mathrm{~m}^{-2} \mathrm{~s}^{-1}\right)$ and the experimental inbred line 201107.2 (group II) also had favorable estimate of $\mathrm{GCA}(A)$ at $63 \mathrm{DAE}-2\left(\hat{g}_{\mathrm{j}}=4.87 \mu \mathrm{mol} \mathrm{CO} \mathrm{m}^{-2} \mathrm{~s}^{-1}\right)$ (Table 3$)$. The highest SCA $(A)$ originated from at least one genitor with positive GCA was from crossing AG8025 x 201-107.2 $\left(\hat{\mathrm{s}}_{\mathrm{ij}}\right.$ $=5.03 \mu \mathrm{mol} \mathrm{CO} \mathrm{m}^{-2} \mathrm{~s}^{-1}$ ) (Table 3), as well as the highest (A) mean observed, with a value of $38.24 \mu \mathrm{mol} \mathrm{CO}_{2} \mathrm{~m}^{-2} \mathrm{~s}^{-1}$ (Supplement1).
The predominance of additive effects in the control of $(A)$ verified in the evaluations at 42 DAE-1 and at 63 DAE-2 (Table 1) implies that in the present work there are potentially favorable genitors to the increase of $\mathrm{CO}_{2}$ assimilation (Coelho et al., 2014). It is worth pointing out that it is important to improve $\mathrm{CO}_{2}$ assimilation, since about $90 \%$ of the plant dry mass originates from $\mathrm{CO}_{2}$ fixation, through the photosynthesis process and the regulation of photosynthetic efficiency (Ali et al., 2014a; Magalhaes; Souza, 2009; Minow et al., 2018). 
01 Season $\mathbf{2} 2$ Season

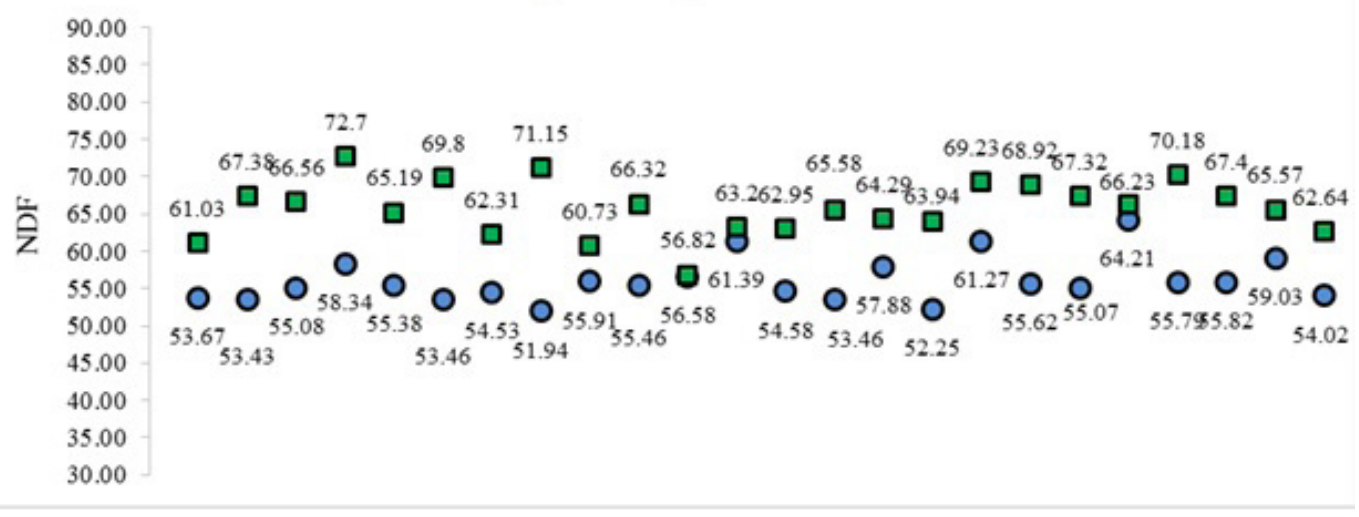

01 Season $\mathbf{2} 2$ Season

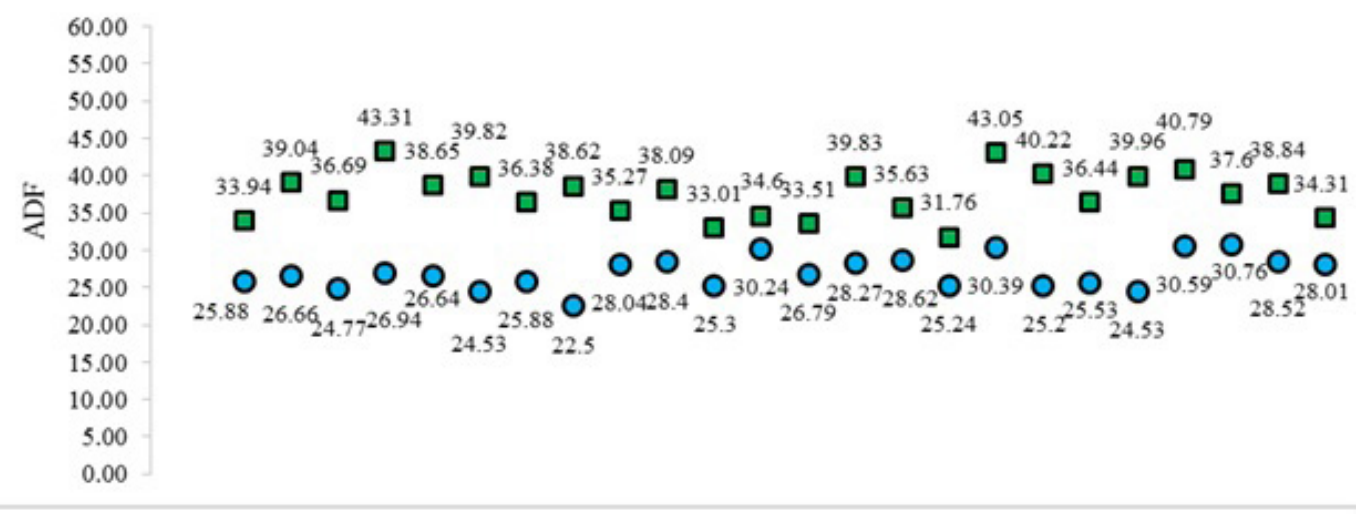

$\mathbf{0}_{1}$ Season $\mathbf{Q}_{2}$ Season

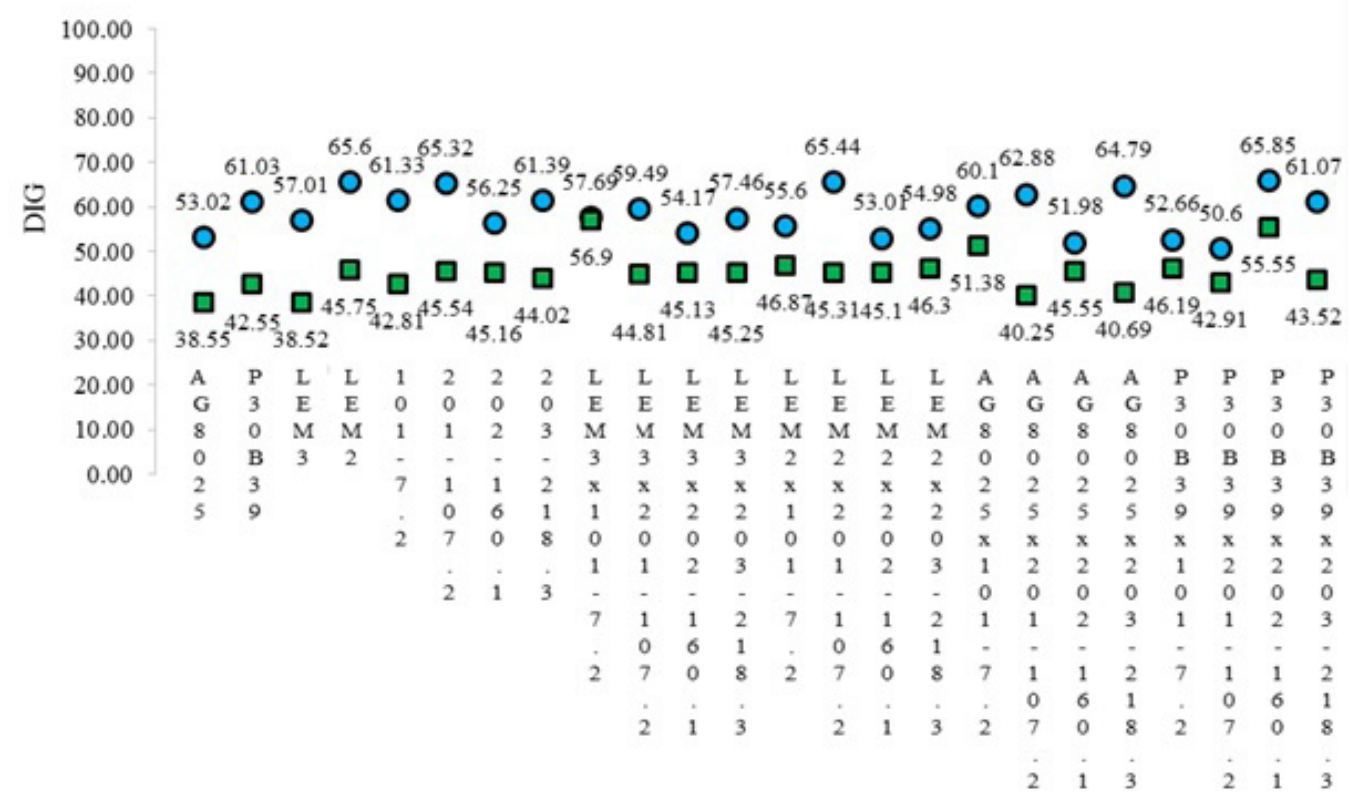

Figure 1: Means of variables neutral detergent fiber (NDF), acid detergent fiber (ADF) and digestibility (DIG), evaluated in two crops seasons in Guarapuava-PR. 
The highest estimates of the SCA of stomatal conductance $(g s)$ at 42 DAE-1 occurred in crossings LEM2 x 202-160.1 (0.21 mol m-2 $\left.\mathrm{s}^{-1}\right)$ and LEM2 x 203-218.3 (0.19 $\mathrm{mol} \mathrm{m} \mathrm{s}^{-1}$ ), but they originate from genitors with GCA estimates negative or close to zero (Table 4), with moderate means (Supplement 2), indicating that the performnce of these genitors was not different from the general mean of the other genitors involved in the crossings (Hallauer; Carena; Miranda Filho, 2010; Hlatywayo et al., 2016).

In the evaluation carried out at $42 \mathrm{DAE}-1$, the crossing P30B39 x 201-107.2 presented the highest SCA $(C i)$ estimate $\left(\hat{\mathrm{s}}_{\mathrm{ij}}=2.48 \mu \mathrm{mol} \mathrm{CO} \mathrm{mol}^{-1}\right.$ air $)$ in which both parents had favorable estimates of $\mathrm{GCA}(\mathrm{Ci})$ (Table 5) and, also, the highest mean among the genotypes, with $229.76 \mu \mathrm{mol}$ $\mathrm{CO}_{2} \mathrm{~mol}^{-1}$ (Supplement 3).

At 63 DAE-1, tester inbred line LEM2 presented the highest estimate of $\mathrm{GCA}(\mathrm{Ci})$ among the genotypes of group I ( $\hat{g}_{\mathrm{i}}=18.59 \mu \mathrm{mol} \mathrm{CO} \mathrm{mol}^{-1}$ air $)$ and participated in the crossing of a high SCA $(C i)$ estimate, LEM $2 \times 202-$ $160.1\left(\hat{\mathrm{s}}_{\mathrm{ij}}=30.07 \mu \mathrm{mol} \mathrm{CO} \mathrm{mol}^{-1}\right.$ air $)$. At $84 \mathrm{DAE}-1$, the highest estimate of SCA (Ci) in which both parents had favorable estimates of GCA $(\mathrm{Ci})$ occurred in crossing LEM3 $\times 202-160.1$, whose $s_{\mathrm{ij}}$ estimate was greater than twice the standard deviation $\left(\hat{\mathrm{s}}_{\mathrm{ij}}=31.65 \mu \mathrm{mol} \mathrm{CO} \mathrm{mol}^{-1}\right.$ air) (Table 5).

Genitor P30B39 had favorable estimates of $\mathrm{GCA}(C i)$ at $21 \mathrm{DAE}-2\left(\hat{g}_{\mathrm{i}}=9.18 \mu \mathrm{mol} \mathrm{CO} \mathrm{mol}^{-1}\right.$ air $)$ and at 63 DAE-2 CGC $\left(\hat{g}_{\mathrm{i}}=8,6446 \mu \mathrm{mol} \mathrm{CO}_{2} \mathrm{~mol}^{-1}\right.$ air $)$ and participated in crossing P30B39 x 202-160.1, which had high SCA estimates in the respective evaluations $\left(\hat{\mathrm{s}}_{\mathrm{ij}}\right.$ $=16.55 \mu \mathrm{mol} \mathrm{CO} \mathrm{mol}^{-1}$ air and $\hat{\mathrm{s}}_{\mathrm{ij}}=10.78 \mu \mathrm{mol} \mathrm{CO} \mathrm{CO}_{2}$ $\mathrm{mol}^{-1}$ air), demonstrating that tester P30B39 allowed to discriminate the most favorable inbred line to improve $\mathrm{Ci}$. Also, at 63 DAE-2, the tester P30B39 participated in the crossing of the highest estimate of SCA (P30B39 x 203218.3; $\hat{\mathrm{s}}_{\mathrm{ij}}=23.46 \mu \mathrm{mol} \mathrm{CO} \mathrm{mol}^{-1}$ air) (Table 5).

Ali et al. (2014b) indicated that the selection based on internal $\mathrm{CO}_{2}$ concentration can be useful in the development of maize hybrids with forage purpose, since the authors verified a direct relationship between the $C i$ and the accumulation of dry mass.

As for group II, at 63 DAE-1, the estimates of GCA (E) that stand out were from inbred lines 101-7.2 $\left(\hat{g}_{\mathrm{i}}=0.55\right.$ mmol water vapor $\left.\mathrm{m}^{-2} \mathrm{~s}^{-1}\right)$ and 202-160-1 $\left(\hat{g}_{\mathrm{i}}=0.46 \mathrm{mmol}\right.$ water vapor $\mathrm{m}^{-2} \mathrm{~s}^{-1}$ ). At 63 DAE-1, the crossing LEM-3 x 202-160.1, in which both parents had favorable estimates of $\operatorname{GCA}(E)$, presented the highest estimate of SCA $(E)$ (Table 6 ) and high mean of transpiration $(E)$ (Supplement 4 ).

The highest estimate of the GCA of transpiration $(E)$ at 42 DAE-1 was from tester LEM2 $\left(\hat{g}_{\mathrm{i}}=0.33\right.$ mmol water vapor $\mathrm{m}^{-2} \mathrm{~s}^{-1}$ ) (Table 6) which generate the hybrid LEM-2 x 202-160.1 of both parents with favorable estimates of GCA $\left(\hat{\mathrm{s}}_{\mathrm{ij}}=0.58 \mathrm{mmol}\right.$ water vapor $\left.\mathrm{m}^{-2} \mathrm{~s}^{-1}\right)$. Regarding the SCA of transpiration $(E)$, the hybrid combination that stood out was LEM3 $\times 201-107.2$ $\left(\hat{\mathrm{s}}_{\mathrm{ij}}=1.02 \mathrm{mmol}\right.$ water vapor $\left.\mathrm{m}^{-2} \mathrm{~s}^{-1}\right)$, whose genitors had positive estimates of $\mathrm{GCA}(E)$ at $42 \mathrm{DAE}-1$, and also high means (Supplement 4).

At 21 DAE-2, the inbred lines LEM $3\left(\hat{g}_{\mathrm{i}}=0.31\right.$ mmol water vapor $\left.\mathrm{m}^{-2} \mathrm{~s}^{-1}\right)$ and 203-218.3 $\left(\hat{g}_{\mathrm{i}}=0.39 \mathrm{mmol}\right.$ water vapor $\mathrm{m}^{-2} \mathrm{~s}^{-1}$ ) had the highest estimates of $\mathrm{GCA}(E)$ (Table 6). The evaluation of transpiration rate of young plants can be effective in the selection of maize genotypes aiming at better photosynthetic efficiency, as higher stomatal conductance causes the increase of $E$, which increases internal $\mathrm{CO}_{2}$ concentration and, consequently, causes an increase of the photosynthetic rate, directly reflecting on forage quality (Ali et al., 2013).

Table 4: Estimates of general combining ability $\left(\hat{g}_{\mathrm{i}}\right.$ and $\left.\hat{g}_{\mathrm{i}}\right)$ and specific combining ability $\left(\hat{\mathrm{s}}_{\mathrm{ii}}\right)$ for stomatal conductance $(\mathrm{gs})\left(\mathrm{mol} \mathrm{m}^{-2} \mathrm{~s}^{-1}\right)$, of 24 maize genotypes evaluated in a $4 \times 4$ partial diallel on 42 days after emergence in the first crop season (DAE-1), in Guarapuava-PR.

\begin{tabular}{ccccccc}
\hline & \multicolumn{6}{c}{ Group II } \\
\cline { 2 - 7 } & Group I & & $101-7.2$ & $201-107.2$ & $202-160.1$ & $203-218.3$ \\
\cline { 2 - 7 } Evaluation & & GCA & 0.00 & -0.01 & 0.02 & -0.01 \\
42 DAE-1 & LEM3 & -0.06 & 0.01 & 0.16 & 0.09 & 0.00 \\
15t Crop Season & LEM2 & -0.04 & 0.05 & 0.13 & 0.21 & 0.19 \\
& AG8025 & -0.00 & 0.03 & -0.01 & 0.09 & 0.12 \\
& P30B39 & 0.10 & 0.04 & 0.01 & 0.08 & -0.10 \\
\hline & SD $\left(\mathrm{s}_{i j}\right): 0.93$ & \multicolumn{5}{c}{$\mathrm{SD}\left(\mathrm{s}_{\mathrm{ij}}\right): 0.12$} \\
\hline
\end{tabular}


Table 5: Estimates of general combining ability $\left(\hat{g}_{\mathrm{i}}\right.$ and $\left.\hat{g}_{\mathrm{i}}\right)$ and specific combining ability $\left(\hat{\mathrm{S}}_{\mathrm{ij}}\right)$ of internal $\mathrm{CO}_{2}$ concentration (Ci) ( $\mu \mathrm{mol} \mathrm{CO}_{2} \mathrm{~mol}^{-1}$ air), of 24 maize genotypes evaluated in a $4 \times 4$ partial diallel at 42,63 and 84 days after emergence in the first season (DAE-1) and at 21 and 63 days after emergence in the second crop season (DAE-2), in Guarapuava-PR.

\begin{tabular}{|c|c|c|c|c|c|c|}
\hline \multirow{7}{*}{$\begin{array}{c}\text { Evaluation } \\
42 \text { DAE-1 } \\
1^{\text {st }} \text { Crop Season }\end{array}$} & & & \multicolumn{4}{|c|}{ Group II } \\
\hline & \multicolumn{2}{|l|}{ Group I } & $101-7.2$ & 201-107.2 & $202-160.1$ & 203-218.3 \\
\hline & & GCA & -0.67 & 0.25 & 1.69 & -1.27 \\
\hline & LEM3 & -2.72 & 4.96 & -2.11 & 2.20 & -2.54 \\
\hline & LEM2 & -3.68 & 2.65 & 0.83 & -0.69 & -3.35 \\
\hline & AG8025 & 2.34 & 0.15 & -5.62 & -0.95 & 2.60 \\
\hline & P30B39 & 4.07 & -1.56 & 2.48 & -5.43 & 0.58 \\
\hline & \multicolumn{2}{|l|}{$S D\left(S_{i j}\right): 3.86$} & \multicolumn{4}{|c|}{$\mathrm{SD}\left(\mathrm{S}_{\mathrm{ij}}\right): 4.01$} \\
\hline \multirow{8}{*}{$\begin{array}{c}\text { Evaluation } \\
63 \text { DAE-1 } \\
1^{\text {st }} \text { Crop Season }\end{array}$} & & & \multicolumn{4}{|c|}{ Group II } \\
\hline & \multicolumn{2}{|l|}{ Group I } & $101-7.2$ & 201-107.2 & $202-160.1$ & 203-218.3 \\
\hline & & GCA & -5.45 & 14.43 & -7.46 & -1.51 \\
\hline & LEM3 & -10.33 & 12.37 & 0.32 & -16.78 & 38.53 \\
\hline & LEM2 & 18.59 & -28.59 & -36.40 & 30.07 & -35.75 \\
\hline & AG8025 & -0.25 & -15.45 & -6.03 & 8.38 & -9.09 \\
\hline & Р30B39 & -8.00 & 26.00 & 5.24 & 12.39 & -8.95 \\
\hline & \multicolumn{2}{|l|}{$S D\left(S_{j j}\right): 13.52$} & \multicolumn{4}{|c|}{$\mathrm{SD}\left(\mathrm{S}_{\mathrm{ij}}\right): 24.01$} \\
\hline \multirow{8}{*}{$\begin{array}{c}\text { Evaluation } \\
84 \text { DAE-1 } \\
1^{\text {st }} \text { Crop Season }\end{array}$} & & & \multicolumn{4}{|c|}{ Group II } \\
\hline & \multicolumn{2}{|l|}{ Group I } & $101-7.2$ & 201-107.2 & $202-160.1$ & 203-218.3 \\
\hline & & GCA & 1.89 & -3.73 & 4.83 & -3.00 \\
\hline & LEM3 & 3.17 & -13.08 & -23.67 & 31.65 & 15.59 \\
\hline & LEM2 & -3.66 & 47.41 & 27.37 & -21.75 & -18.97 \\
\hline & AG8025 & 1.61 & 4.78 & -19.31 & 14.56 & -2.52 \\
\hline & P30B39 & -1.12 & 7.48 & -7.44 & 4.47 & 3.54 \\
\hline & \multicolumn{2}{|c|}{$S D\left(S_{j j}\right): 14.20$} & \multicolumn{4}{|c|}{$S D\left(S_{i j}\right): 13.41$} \\
\hline \multirow{8}{*}{$\begin{array}{c}\text { Evaluation } \\
21 \text { DAE-2 } \\
2^{\text {nd }} \text { Crop Season }\end{array}$} & & & \multicolumn{4}{|c|}{ Group II } \\
\hline & \multicolumn{2}{|l|}{ Group I } & $101-7.2$ & 201-107.2 & $202-160.1$ & 203-218.3 \\
\hline & & GCA & 1.52 & -0.45 & 2.10 & -3.17 \\
\hline & LEM3 & -3.92 & -7.78 & -4.20 & -5.61 & -1.54 \\
\hline & LEM2 & 1.64 & 14.75 & 0.03 & -13.54 & -3.91 \\
\hline & AG8025 & -6.90 & 6.53 & 2.40 & 2.40 & -1.53 \\
\hline & P30B39 & 9.18 & -23.86 & 0.62 & 16.55 & 13.78 \\
\hline & \multicolumn{2}{|l|}{$S D\left(S_{j j}\right): 6.29$} & \multicolumn{4}{|c|}{$S D\left(S_{i j}\right): 8.16$} \\
\hline \multirow{8}{*}{$\begin{array}{c}\text { Evaluation } \\
63 \text { DAE-2 } \\
2^{\text {nd }} \text { Crop Season }\end{array}$} & & & \multicolumn{4}{|c|}{ Group II } \\
\hline & \multicolumn{2}{|l|}{ Group I } & $101-7.2$ & 201-107.2 & $202-160.1$ & 203-218.3 \\
\hline & & GCA & -0.20 & -3.49 & 3.48 & 0.21 \\
\hline & LEM3 & -10.66 & 4.24 & -5.92 & 6.05 & 4.73 \\
\hline & LEM2 & 2.72 & -15.43 & 8.95 & 17.73 & 14.38 \\
\hline & AG8025 & -0.70 & 22.83 & -3.67 & -15.11 & -14.58 \\
\hline & Р30B39 & 8.64 & -0.13 & -24.97 & 10.78 & 23.46 \\
\hline & \multicolumn{2}{|c|}{$\mathrm{SD}\left(\mathrm{S}_{\mathrm{j} j}\right): 12.95$} & \multicolumn{4}{|c|}{$\mathrm{SD}\left(\mathrm{S}_{\mathrm{ij}}\right): 16.80$} \\
\hline
\end{tabular}


Table 6: Estimates of general combining ability $\left(\hat{g}_{i}\right.$ and $\left.\hat{g}_{j}\right)$ and specific combining ability $\left(\hat{\mathrm{s}}_{i j}\right)$ of transpiration $(E)$ ( $\mathrm{mmol}$ water vapor $\mathrm{m}^{-2} \mathrm{~s}^{-1}$ ), of 24 maize genotypes evaluated in a $4 \times 4$ partial diallel at 42,63 and 84 days after emergence in the first crop season (DAE-1) and at 21 days after emergence in the second crop season (DAE-2), in Guarapuava-PR.

\begin{tabular}{|c|c|c|c|c|c|c|}
\hline \multirow{8}{*}{$\begin{array}{c}\text { Evaluation } \\
42 \text { DAE-1 } \\
1^{\text {st }} \text { Crop Season }\end{array}$} & & & \multicolumn{4}{|c|}{ Group II } \\
\hline & \multicolumn{2}{|l|}{ Group I } & $101-7.2$ & 201-107.2 & $202-160.1$ & $203-218.3$ \\
\hline & & GCA & 0.06 & 0.04 & 0.14 & -0.25 \\
\hline & LEM3 & 0.07 & -0.67 & 1.02 & 0.28 & -0.61 \\
\hline & LEM2 & 0.33 & 0.24 & -0.15 & 0.58 & 0.90 \\
\hline & AG8025 & -0.56 & 0.23 & 0.42 & -0.21 & 0.38 \\
\hline & P30B39 & 0.15 & 0.67 & 0.26 & 0.09 & -1.81 \\
\hline & \multicolumn{2}{|l|}{$S D\left(S_{j j}\right): 0.50$} & \multicolumn{4}{|c|}{$S D\left(S_{i j}\right): 0.65$} \\
\hline \multirow{8}{*}{$\begin{array}{c}\text { Evaluation } \\
63 \text { DAE-1 } \\
1^{\text {st }} \text { Crop Season }\end{array}$} & & & \multicolumn{4}{|c|}{ Group II } \\
\hline & \multicolumn{2}{|l|}{ Group I } & $101-7.2$ & 201-107.2 & $202-160.1$ & $203-218.3$ \\
\hline & & GCA & 0.55 & -0.62 & 0.46 & -0.38 \\
\hline & LEM3 & 0.21 & 0.53 & 1.41 & 1.13 & -0.35 \\
\hline & LEM2 & 0.00 & 1.23 & 0.07 & -0.44 & 1.50 \\
\hline & AG8025 & -0.09 & 0.92 & -1.33 & 0.87 & -0.41 \\
\hline & P30B39 & -0.12 & 0.43 & -0.59 & -0.78 & 0.45 \\
\hline & \multicolumn{2}{|l|}{$S D\left(S_{j j}\right): 0.42$} & \multicolumn{4}{|c|}{$\mathrm{SD}\left(\mathrm{S}_{\mathrm{ij}}\right): 1.00$} \\
\hline \multirow{8}{*}{$\begin{array}{c}\text { Evaluation } \\
84 \text { DAE-1 } \\
1^{\text {st }} \text { Crop Season }\end{array}$} & & & \multicolumn{4}{|c|}{ Group II } \\
\hline & \multicolumn{2}{|l|}{ Group I } & $101-7.2$ & 201-107.2 & $202-160.1$ & $203-218.3$ \\
\hline & & GCA & 0.75 & -0.41 & -0.08 & -0.24 \\
\hline & LEM3 & 0.38 & 0.63 & -0.21 & -0.62 & 0.27 \\
\hline & LEM2 & 0.21 & 0.91 & -1.97 & -0.75 & -0.40 \\
\hline & AG8025 & -0.08 & 0.21 & 0.37 & -0.54 & -0.73 \\
\hline & Р30B39 & -0.51 & 0.00 & -1.70 & -099 & 0.15 \\
\hline & \multicolumn{2}{|l|}{$S D\left(S_{j j}\right): 0.67$} & \multicolumn{4}{|c|}{$\mathrm{SD}\left(\mathrm{S}_{\mathrm{ij}}\right): 1.26$} \\
\hline \multirow{8}{*}{$\begin{array}{c}\text { Evaluation } \\
21 \text { DAE-2 } \\
2^{\text {nd }} \text { Crop Season }\end{array}$} & & & \multicolumn{4}{|c|}{ Group II } \\
\hline & Group I & & $101-7.2$ & 201-107.2 & $202-160.1$ & $203-218.3$ \\
\hline & & GCA & -0.17 & -0.14 & -0.06 & 0.39 \\
\hline & LEM3 & 0.31 & -0.52 & -1.01 & 0.24 & -0.76 \\
\hline & LEM2 & 0.15 & 0.96 & -0.76 & -0.16 & 0.52 \\
\hline & AG8025 & -0.38 & 1.34 & 0.43 & 0.79 & -0.62 \\
\hline & P30B39 & -0.07 & -0.77 & -0.24 & -0.63 & 0.35 \\
\hline & \multicolumn{2}{|l|}{$S D\left(S_{j j}\right): 0.30$} & \multicolumn{4}{|c|}{$S D\left(S_{i j}\right): 0.65$} \\
\hline
\end{tabular}

Tester AG8025 obtained the highest estimates of GCA $(A / C i)$ at 84 DAE-1 $\left(\hat{g}_{\mathrm{i}}=0,28\right)$, and at 21 DAE-2 $\left(\hat{g}_{\mathrm{i}}=0,95\right)$. Also, at 21 DAE-2 inbred line 203-218.3 $\left(\hat{g}_{j}\right.$ $=1.41)$ participated in the crossing with the highest $\mathrm{SCA}$
(LEM3 x 203-218.3) $\left(\hat{\mathrm{s}}_{\mathrm{ij}}=4.34 \mu \mathrm{mol} \mathrm{m}^{-2} \mathrm{~s}^{-1} \mathrm{~Pa}^{-1}\right)$ (Table 7). The $\mathrm{A} / \mathrm{C} i$ ratio reveals the carboxylation efficiency of the 1.5-bisphophate carboxylase enzyme ribulose (Rubisco), that is, how much $\mathrm{CO}_{2}$ was reduced in the photosynthesis 
process (Chen; Mi, 2018; Muraya et al., 2017). Therefore, high and positive estimates of GCA and SCA are desireble. The experimental inbred line 101-7.2 $\left(\hat{g}_{\mathrm{j}}=0.37\right)$ had the highest estimate of GCA $(\mathrm{A} / \mathrm{Ci})$ at 63 DAE-1 (Table 7) and the highest mean of $A / C i$ was observed in crossing LEM3 $\mathrm{x}$ 202-160.1 (0.86 $\left.\mu \mathrm{mol} \mathrm{m}^{-2} \mathrm{~s}^{-1} \mathrm{~Pa}^{-1}\right)$ (Supplement 5), as well as the highest SCA $(A / C i)\left(\hat{\mathrm{s}}_{\mathrm{ij}}=0.56 \mu \mathrm{mol} \mathrm{m}^{-2} \mathrm{~s}^{-1} \mathrm{~Pa}^{-1}\right)$.

The $A / E$ ratio reveals the efficiency of water use and reflects the plant's ability to limit water loss and, at the same time, allows $\mathrm{CO}_{2}$ absorption (Taiz; Zeiger, 2013).
At 42 DAE-1 the inbred line 203-218.3 $\left(\hat{g}_{\mathrm{j}}=\right.$ $\left.0.17 \mu \mathrm{mol} \mathrm{CO} / \mathrm{mmol} \mathrm{H}_{2} \mathrm{O}^{-1}\right)$ stood out, as well as the crossing P30B39 x 203-218.3 $\left(\hat{\mathrm{s}}_{\mathrm{ij}}=0.24 \mu \mathrm{mol} \mathrm{CO} / \mathrm{mmol}\right.$ $\mathrm{H}_{2} \mathrm{O}^{-1}$ ) (Table 8), which obtained the highest mean of $A / E$ (3.45 $\mu \mathrm{mol} \mathrm{CO}_{2} / \mathrm{mmol} \mathrm{H}_{2} \mathrm{O}^{-1}$ ) (Supplement 6).

The inbred line 201-107.2 presented high GCA $(A / E)$ estimate at 63 DAE-1 $\left(\hat{g}_{\mathrm{j}}=2.21 \mu \mathrm{mol} \mathrm{CO} / \mathrm{mmol}\right.$ $\left.\mathrm{H}_{2} \mathrm{O}^{-1}\right)$ and was the only of group II that presented positive estimates of GCA $(A / E)$ at $84 \mathrm{DAE}-1\left(\hat{g}_{\mathrm{j}}=0.48 \mu \mathrm{mol} \mathrm{CO} /\right.$ $\left.\mathrm{mmol} \mathrm{H}_{2} \mathrm{O}^{-1}\right)$ and at 63 DAE-2 $\left(\hat{g}_{\mathrm{j}}=0.38 \mu \mathrm{mol} \mathrm{CO} / \mathrm{mmol}\right.$ $\left.\mathrm{H}_{2} \mathrm{O}^{-1}\right)$ (Table 8 and Supplement 6).

Table 7: Estimates of general combining ability $\left(g_{i}\right.$ and $\left.g_{j}\right)$ and specific combining ability $\left(\hat{s}_{i j}\right)$ for calculated activity of Rubisco $(A / C i)\left(\mu \mathrm{mol} \mathrm{m}^{-2} \mathrm{~s}^{-1} \mathrm{~Pa}^{-1}\right)$, of 24 maize genotypes evaluated in a $4 \times 4$ partial diallel at 63 and 84 days after emergence in the first crop season (DAE-1) and at 21 and 63 days after emergence in the second crop season (DAE-2), in Guarapuava-PR.

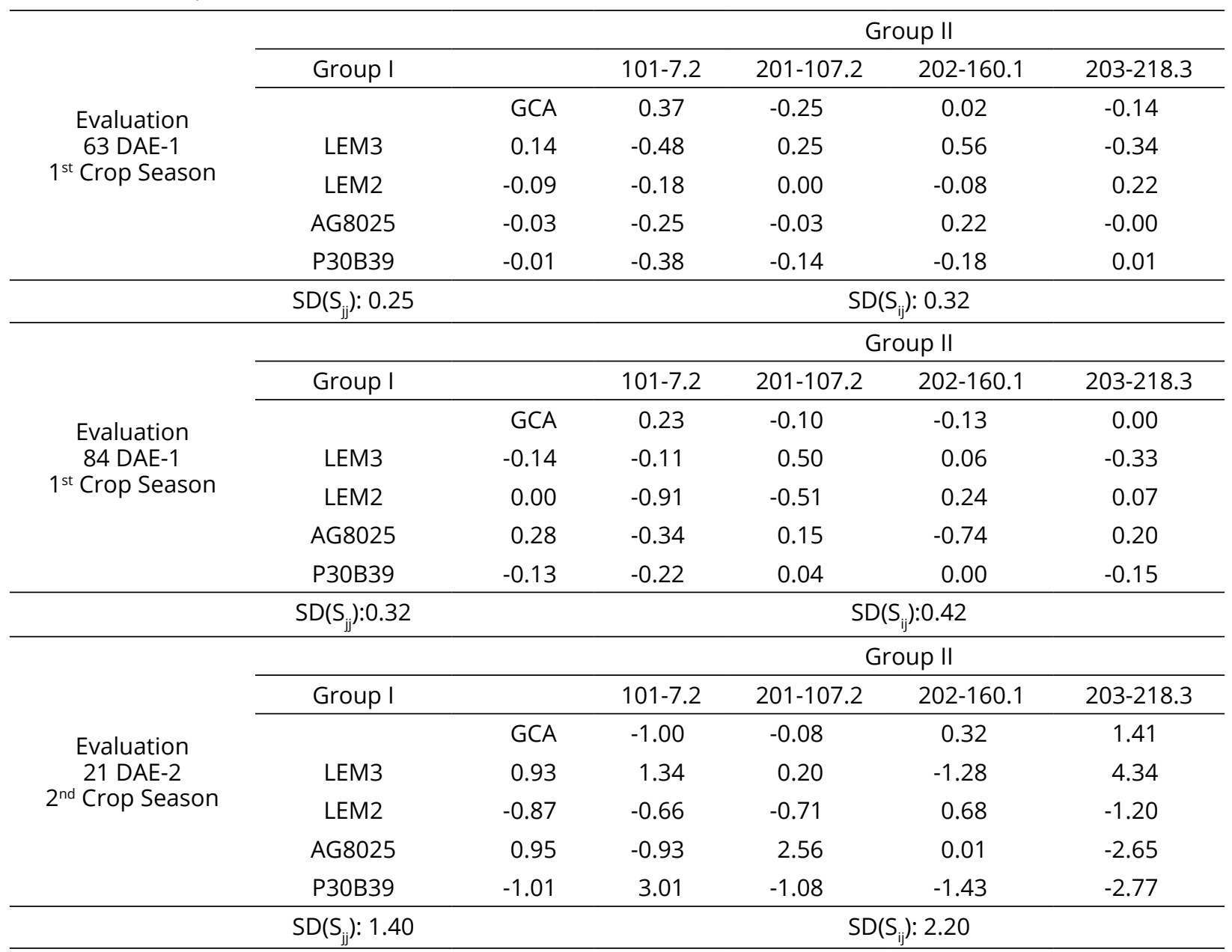


Table 7: Continuation.

\begin{tabular}{ccccccc}
\hline & \multicolumn{6}{c}{ Group II } \\
\cline { 2 - 7 } & Group I & & $101-7.2$ & $201-107.2$ & $202-160.1$ & $203-218.3$ \\
\cline { 2 - 7 } Evaluation & & GCA & -1.04 & 1.27 & -1.74 & 1.51 \\
63 DAE-2 & LEM3 & 1.08 & 6.54 & -0.81 & -1.03 & -5.51 \\
$2^{\text {nd }}$ Crop Season & LEM2 & -1.65 & -0.32 & -2.85 & -0.37 & -3.56 \\
& AG8025 & 1.87 & -4.77 & 18.43 & -0.54 & -5.83 \\
& P30B39 & -1.30 & -0.76 & -1.59 & 0.28 & -3.61 \\
\cline { 2 - 7 } & SD(S $\left(S_{j}\right): 4.37$ & & & & SD $\left(\mathrm{S}_{\mathrm{ij}}\right): 5.66$ & \\
\hline
\end{tabular}

Tabela 8: Estimates of general combining ability ( $g_{i}$ and $\left.g_{j}\right)$ and specific combining ability $\left(\hat{S}_{i j}\right)$ of the efficiency of water use $(A / E)\left(\mu \mathrm{mol} \mathrm{CO} / \mathrm{mmol} \mathrm{H}_{2} \mathrm{O}^{-1}\right)$ of 24 maize genotypes evaluated in a $4 \times 4$ partial diallel at 42,63 and 84 days after emergence in the first crop season (DAE-1) and at 63 days after emergence in the second crop season (DAE-2), in Guarapuava-PR.

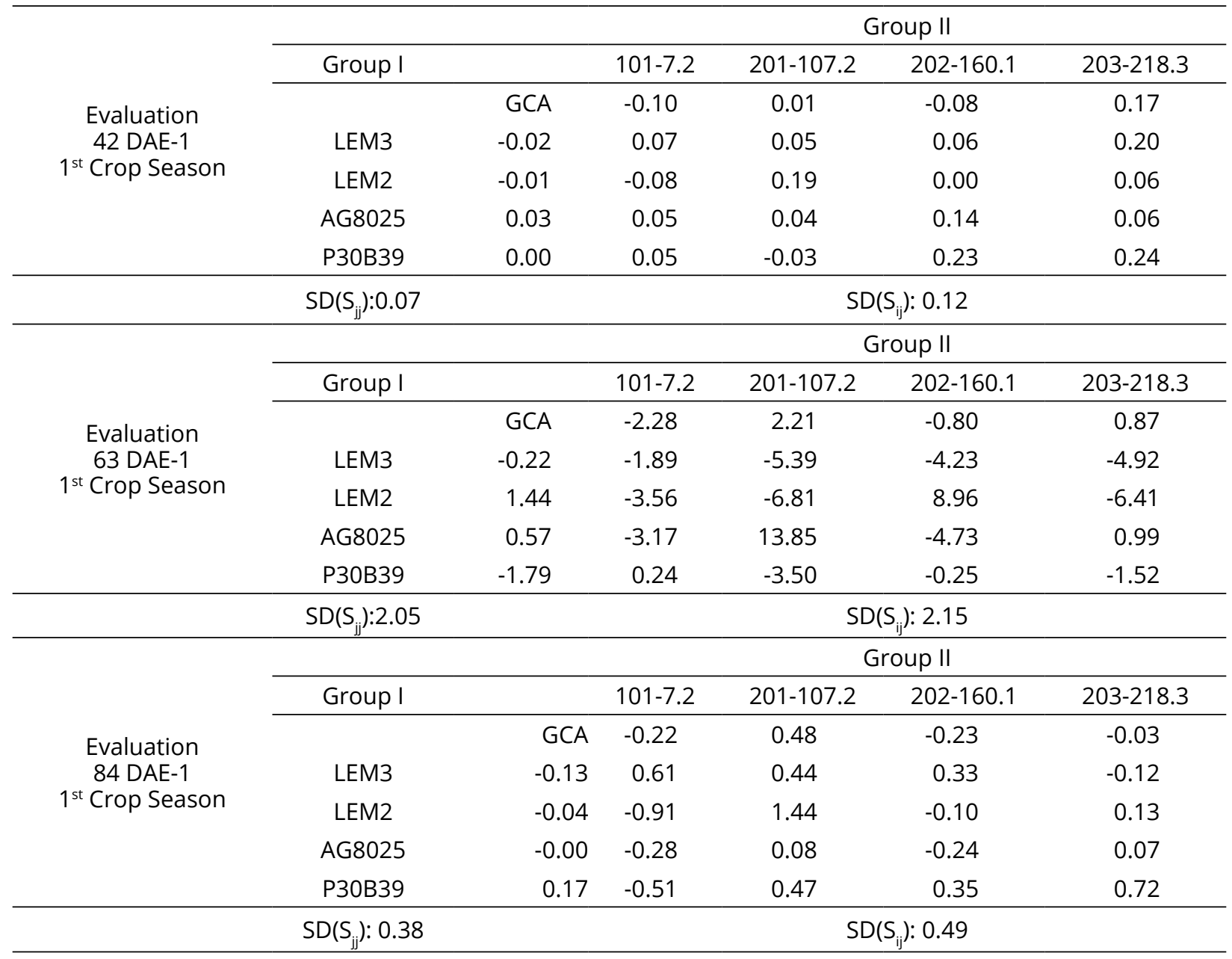


Table 8: Continuation.

\begin{tabular}{ccccccc}
\hline & & \multicolumn{5}{c}{ Group II } \\
\cline { 2 - 7 } & Group I & & $101-7.2$ & $201-107.2$ & $202-160.1$ & $203-218.3$ \\
\cline { 2 - 6 } Evaluation & & GCA & -0.23 & 0.38 & -0.05 & -0.08 \\
63 DAE-2 & LEM3 & 0.22 & 0.27 & 0.11 & -0.18 & -0.07 \\
$2^{\text {nd }}$ Crop Season & LEM2 & 0.10 & 0.00 & -0.63 & 0.09 & 0.12 \\
& AG8025 & -0.07 & -0.63 & 0.40 & 0.01 & 0.82 \\
& P30B39 & -0.25 & 0.12 & 0.71 & -0.15 & -0.64 \\
\hline
\end{tabular}

The inbred line 201-107.2 participated in the crossing with the highest estimate of SCA $(A / E)$ at 63 DAE-1 (AG8025 x 201-107.2; $\hat{\mathrm{s}}_{\mathrm{ij}}=13.85 \mu \mathrm{mol} \mathrm{CO} / \mathrm{mmol}$ $\mathrm{H}_{2} \mathrm{O}^{-1}$ ), in which both parents had favorable estimates of $\mathrm{GCA}(A / E)$. Considering at least one genitor with favorable GCA $(A / E)$, significant estimates of SCA $(A / E)$ were obtained for the crossings involving inbred line 201-107.2, i.e. LEM2 X 201-107.2 $\left(\hat{\mathrm{s}}_{\mathrm{ij}}=1.44 \mu \mathrm{mol} \mathrm{CO} / \mathrm{mmol} \mathrm{H}_{2} \mathrm{O}^{-1}\right)$ at 84 DAE-1 and P30B39 x 201-107.2 $\left(\hat{\mathrm{s}}_{\mathrm{ij}}=0.71 \mu \mathrm{mol}\right.$ $\mathrm{CO}_{2} / \mathrm{mmol} \mathrm{H}_{2} \mathrm{O}^{-1}$ ) at 63 DAE-2 (Table 8).

The high efficiency in water use is directly related to the stomatal opening time, since while the plant absorbs $\mathrm{CO}_{2}$ for the photosynthesis, water is lost by transpiration, with varied intensity, depending on the potential gradient between the foliar surface and the atmosphere, following a chain of water potentials (Muraya et al., 2017; Silva et al., 2015). Thus, it is assumed that more efficient genotypes in water use tend to produce higher amounts of dry mass per gram of transpired water, directly affecting forage performance (Ali et al., 2013).

Given the above, hybrid LEM2 x 101-7.2 presented the highest rate of $\mathrm{CO}_{2}$ assimilation, in addition to desirable values for neutral detergent fiber (NDF) and acid detergent fiber (ADF), in the evaluation of both crop seasons, as well as good digestibility (DIG) (Figure 1). The contents of fiber and digestibility directly reflect on forage quality and it is essential to study them to obtain promising genotypes, justifying the study of both physiological and chemical components, and their effects on forage quality (Ali et al., 2013).

The inbred lines which most contributed to improve DIG, considering the mean values, were the tester LEM2 (group I) and the experimental inbred line 201-107.2 (group II) (Figure 1). Consequently, they presented high $\mathrm{CO}_{2}$ assimilation and high efficiency of water use, which reasserts the relationship of physiological traits with qualitative bromatological traits of the forage, (Figure 1), justifying this study.

\section{CONCLUSIONS}

There was a predominance of non-additive gene effects for most of the chemical and physiological traits. Elite inbred lines LEM2 and LEM3 were the best testers to discriminate the relative merit of the experimental inbred lines. Crossings LEM2x203-218.3, LEM3 x 201107.2, LEM2 x 101-7.2 and LEM3 x 101-7.2 stood out regarding $\mathrm{CO}_{2}$ assimilation, and are indicated for future research considering the physiological traits. Inbred lines 101-7.2 and 203-218.3 presented the high concentration of favorable alleles to increase carboxylation efficiency, in which inbred line 101-7.2 stood out for NDF, ADF and DIG. Inbred line 201-107.2 has a high concentration of favorable alleles for efficiency of water use. Physiological parameters can assist the selection of inbred lines and hybrids in maize breeding for forage purpose.

\section{ACKNOWLEDGEMENTS}

To Fundação Araucária, Conselho Nacional de Desenvolvimento Científico e Tecnológico (CNPq), Financiadora de Estudos e Projetos - FINEP and Coordenação de Aperfeiçoamento de Pessoal de Nível Superior (Capes, Finance Code 001), for financial support.

\section{REFERENCES}

ALI, Q. et al. Genetic correlation and hybrid vigor for physiological traits of Zea mays. Nature and Science, 12(12):1-12, 2014.

$A L I, Q$. et al. Combining ability analysis for various physiological, grain yield and quality traits of Zea mays L. Life Science Journal, 11(8):540-551, 2014a.

$A L I, Q$. et al. Study of gene action for various physiological traits in Zea mays. Report and Opinion, 6(4):71-83, 2014b. 
ALI, Q. M. et al. Genetic variability and correlation among morphological traits of maize (Zea mays $L$ ) seedling. The Albanian Journal of Agricultural Sciences, 12(3):405410, 2013.

ALI, Q. et al. Genetic analysis of Zea mays genotypes for various physiological and plant growth related traits to improve fodder yield. American-Eurasian Journal of Agriculture \& Environmental Science, 15(8):1530-1543, 2015.

ALVAREZ, C. F.; CRUSCIOL, C. A. C.; NASCENTE, A. S. Análise de crescimento e produtividade de cultivares de arroz de terras altas dos tipos tradicional, intermediário e moderno. Pesquisa Agropecuária Tropical, 42(4):397-406, 2012.

CAÑAS, R. A. et al. Exploiting the genetic diversity of maize using a combined metabolomic, enzyme activity profiling, and metabolic modeling approach to link leaf physiology to kernel yield. The Plant Cell, 29(5):919-943, 2017.

CHEN, T. et al. Genetic and environmental dissection of biomass accumulation in multi-genotype maize canopies. Journal of Experimental Botany, 70(9):2523-2534, 2018.

CHEN, Y.; MI, G. Physiological mechanisms underlying postsilking nitrogen use efficiency of high-yielding maize hybrids differing in nitrogen remobilization efficiency. Journal of Plant Nutrition and Soil Science, 181(6):923-931, 2018.

COELHO, C. C. R. et al. Aspectos ecofisiológicos e crescimento em plantas de milho submetidas ao alagamento. Revista Agroecossistemas, 5(2):41-46, 2014.

CRUZ, C. D. GENES - A softaware package for analysis in experimental statistics and quantitative genetics. Acta Scientiarum. Agronomy, 35(3):271-276, 2013.

GERALDI, I. O.; MIRANDA FILHO, J. B. Adapted models for the analysis of combining ability of varieties in partial diallel crosses. Revista Brasileira de Genética,11(2):419-430, 1988.

GRIFFING, B. Concept of general and specific combining ability in relation to diallel crossing systems. Australian Journal of Biology Science, 9(3):463-493, 1956.

GUARDA, V. D. A.; CAMPOS, L. J. M. Bases ecofisiológicas da assimilação de carbono e suas implicações na produção de forragem. Palmas: Embrapa Pesca e Aquicultura, 2014, 47p.

HUANG, S. et al. Influence of plant architecture on maize physiology and yield in the Heilonggang River valley.The Crop Journal, 5(1):52-62, 2017.

HALLAUER, A. R.; CARENA, J. M.; MIRANDA FILHO, J. B. Quantitative genetics in maize breeding. New York: Springer, 2010, 500p.
HLATYWAYO, R. et al. Response of maize (Zea mays L.) secondary growth parameters to conservation agriculture and conventional tillage systems in zimbabwe. Journal of Agricultural Science, 8(11):112-126, 2016.

LINS, F. J. A. et al. Crescimento de genótipos experimentais de milho em função de doses crescentes de nitrogênio. Revista Ciência Agrícola, 15(2):19-27, 2017.

MINOW, M. A. A. et al. Distinct gene networks modulate floral induction of autonomous maize and photoperioddependent teosinte. Journal of Experimental Botany, 69(12):2937-2952, 2018.

MURAYA, M. M. et al. Genetic variation of growth dynamics in maize (Zea maysL.) revealed through automated non-invasive phenotyping. The Plant Journal, 89(2):366-380, 2017.

OLIBONI, R. et al. Análise dialélica na avaliação do potencial de híbridos de milho para a geração de populações-base para obtenção de linhagens. Semina: Ciências Agrárias, 34(1):7-18, 2013.

PEIXOTO, C. P. et al. Análise quantitativa do crescimento de plantas: Conceitos e prática. Enciclopédia Biosfera, 7(13):51-76, 2011.

PEREIRA, M. N. et al. Ruminal degradability of hard or soft texture corn grain at three maturity stages. Scientia Agricola, 61(4):358-363, 2004.

PIMENTEL, C. Carbon metabolism of crops and the increase of atmospheric $\mathrm{CO}_{2}$ and $\mathrm{O}_{3}$ situation and previsions. Bragantia, 70(1):1-12, 2011.

RETTA, M. et al. A two-dimensional microscale model of gas exchange during photosynthesis in maize ( Zea mays L.) leaves. Plant Science, 246:37-51, 2016.

ROSA, J. C. et al. Forage potential of $S_{3}$ corn progenies in topcrosses and selection of testers of different genetic bases. Pesquisa Agropecuária Brasileira, 55:e01283, 2020.

SILVA, F. G. et al. Trocas gasosas e fluorescência da clorofila em plantas de berinjela sob lâminas de irrigação. Revista Brasileira de Engenharia Agrícola e Ambiental, 19(10):946-952, 2015.

SUN, Y. et al. Impact of mesophyll diffusion on estimated global land $\mathrm{CO}_{2}$ fertilization. PNAS, 111(44):15774-15779, 2014.

TAIZ, L.; ZEIGER, E. Fisiologia vegetal. $5^{\circ}$ ed. Porto Alegre: Artmed, 2013, 918p.

TIWARI, D. K. et al. Interfacing carbon nanotubes (CNT) with plants: Enhancement of growth, water and ionic nutrient uptake in maize (Zea mays) and implications for nanoagriculture. Applied Nanoscience, 4(5):577-591, 2014. 
VAN SOEST, P. J.; ROBERTSON, J. B.; LEWIS, B. A. Methods for dietary fiber, neutral detergent fiber, and nonstarch polysaccharides in relation to animal nutrition. Journal of dairy science, 74(10):3583-3597, 1991.

VON CAEMMERER, S.; FARQUHAR, G. D. Some relationships between the biochemistry of photosynthesis and the gas exchange of leaves. Planta, 153(4):376-387, 1981.
WANG, F. et al. Effects of biochar amendment, $\mathrm{CO}_{2}$ elevation and drought on leaf gas exchange, biomass production and water use efficiency in maize. Pakistan Journal of Botany, 50(4):1347-1353, 2018.

WU, L. et al. Comparative proteomic analysis of the response of maize (Zea mays L.) Leaves to long photoperiod condition. Frontiers in Plant Science, 7:752, 2016. 